Thyroid Radioiodine Uptake Measurement A Standard System for Universal Intercalibration. By Dr. Marshall Brucer. Pp. ix + 323. United States Atomic Energy Commission. (Washington, D.C. : Office of Technical Services, Department of Commerce, 1959.) 3.50 dollars,

$7 \mathrm{HE}$ measurement in vivo of the radioactive iodine content of the human thyroid is a deceptively simple procedure. Determinations of this type have been made with increasing frequency during the past twenty years, and are now widely used in the course of elinical diagnosis and radioisotope therapy, as well as in numerous investigations of thyroid function. It has long been known, however, that the calibration involved in such measurements depended critically upon the spectral sensitivity and shielding of the counting equipment used, as well as upon its geometrical relationship to the thyroid and the effects of seattering and absorption of radiation in the neek tissues.

In the course of discussions at Oak Ridge in 1953, and of subsequent inter-calibration measurements, it became clear that many laboratories and hospital departments were relying on inappropriate and quite inadequate techniques of calibration, and that gross systematic errors were being made in the estimation of the radioiodine content of the gland and therefore in the percentage uptake of any dose, since the in vitro measurements of the dose were not subject to corresponding discrepancies. The present publication by Dr. Marshall Brucer describes at length the effects upon the observed counting-rate of the counter shielding and collimation, the counter type and spectral sensitivity, the thyroid position, the scattering and absorption of radiation by body tissues, and the body content of radioiodine at the time of the measurement.

The book gives the text of a series of lectures on upteke measurements, and preserves their bulk and narrative character, with numerous explanatory diagrams and a non-mathematical form, and without any attempt to achieve a compact or formal analysis which would in any case be awkward in so practical and applied a problem. The material discussed will be of considerable value to those concerned with similar in vivo measurements and whose methods have not been subjected to detailed examination of this type. E. E. POCHIN

The Metabolism of Sulphur Compounds By Leslie Young and George A. Maw. Pp. 180. (London: Methuen and Co., Ltd., 1958.) 16s.

7 HIS small book, one of the Methuen "Monographs on Biochemical Subjects", succeeds admirably in its object of giving a general survey of the metabolism of sulphur-containing substances. It directs attention to the great diversity of sulphur compounds in Nature, but deals, from the metabolic aspect, with many substances which have not been found in living organisms in addition to those of natural occurrence. The reader cannot fail to note the uncertainties which still exist regarding the precise course of the most important metabolic processes, such as the desulphuration of cysteine, the oxidation of this substance to sulphate, its conversion to taurine and finally its synthesis in micro-organisms. The formation of thiosulphate is also imperfectly understood. It is perhaps significant of the way in which the study of sulphur metabolism has developed that the authors have virtually restricted themselves to higher animals and micro-organisms and that the latter are dealt with in a single chapter. Although the authors state that plants and micro-organisms are responsible for the greater part of the interconversion of sulphur compounds in Nature, practically nothing is said of sulphur metabolism in plants; several unusual compounds which occur in plants are nevertheless mentioned. The authors, experts on their subject, have covered, however, the metabolism of sulphur compounds in higher animals in the widest possible manner, and are to be congratulated on producing a critical, well-written, informative and thoroughly documented introductory text-book.

G. D. Grevilue

\section{Health in Industry}

By Donald Hunter. (Pelican Book A441.) Pp. $288+$ 18 plates. (Harmondsworth, Middx.: Penguin Books, Ltd., 1959.) $4 s$.

THE history of occupational disease spreads over many years and, until comparatively recently, ailments like beat knee, 'stagmus', writer's cramp, grocer's itch and cotton-workers' throat were accepted as heavenly or other visitations about which little could be done. With the growth of the industrial revolution the number of diseases multiplied so much in factory, workshop and mine that few industrial workers were able to get through a life-time free from occupational disease.

Since the industrial revolution began in Britain, it was fitting that British doctors should first assume responsibility for the health of the workers. This interesting book by a senior physician to the London Hospital, and one who has had long experience in industrial medicine, describes the genesis of industrial medical services and the way they have developed. Rightly, the author emphasizes that in this field prevention is better than cure, and that responsibility for prevention rests not only upon doctors but also upon the Government, architects, management, trede unions and the workers they represent.

\section{T. H. HaWkINS}

\section{Fertilizers and Profitable Farming}

By Dr. G. W. Cooke. Pp. xviii + 122. (London: Crosby Lockwood and Son, Ltd., 1959.) 15s. net.

TN this small book Dr. G. W. Cooke, head of the 1 Department of Chemistry at the Rothamsted Experimental Station, has presented the substance of a series of lectures given to farmers. It is a straightforward account of how commercial fertilizers can be used to the greatest economic advantage. This has now become a matter of major concern to most arable farmers, and, though much of it is a matter of common sense rather than applied science, experimental results obtained in research fields and laboratories have supplied valuable quantitative data on which generalized recommendations about amounts, composition and application of fertilizers to different crops can be based. Dr. Cooke has used such data to make recommendations for fertilizing the principal British arable crops and grassland, and points out what adjustments are required for different conditions of soil and climate. The book is packed with useful information, but is too short to cover adequately operations on which British farmers spend $£ 90$ million a year. It deserves a better index than it has been given. G. V. JACks 